\title{
The Effectiveness of Cooperative Learning Model Type MURDER Assisted by Interactive Quiz Media on Student Learning Outcomes
}

\author{
Rini Anggraeni1, ${ }^{1,}$, Kokom Komalasari $^{2}$ \\ ${ }^{1,2}$ Universitas Pendidikan Indonesia, Bandung, Indonesia \\ *Corresponding author. Email: rinianggraeni@upi.edu
}

\begin{abstract}
This study aims to determine the effect of cooperative learning model, mood, understand, recall, detect, expand, review assisted by interactive quiz on student learning outcomes. Since the pandemic has spread throughout the world, it has had an impact on various fields, including in the field of learning in Indonesia. Where there are learning models and media used by teachers in teaching. A teacher must use an innovative and creative learning model that is applied in every lesson well, so that students get optimal learning outcomes. Learning outcomes also provide an overview of the level of achievement that has been taken by students in the cognitive, affective, and psychomotor aspects. Achieving optimal learning outcomes can be achieved through an effective learning process. Because many students do not reach minimum completeness criteria in the Citizenship Education subject Yapiq Soreang, an innovation is needed by the teacher as an effort to improve learning outcomes, by applying innovative learning models, providing meaningful learning experiences that are able to attractstudents' interest in learning. . This study used a quantitative approach with a quasi-experimental method consisting of research samples given different treatments. The exper imental class applies mood, understand, recall, detect, expand, review cooperative model with interactive quiz media while the control class applies the Student Teams Achievement Divisions model.
\end{abstract}

Keywords : Cooperative Learning, Interactive Quiz, Learning Outcomes, MURDER Type.

\section{INTRODUCTION}

Learning is a process of reciprocal relationship between a teacher and his students in learning activities to achieve learning objectives. The learning process can be said to be successful if every teacher and student can work together in realizing conducive learning. A teacher should ideally be able to give a perfect role in determining and applying learning models to convey knowledge so that students want to learn and achieve optimal learning outcomes. The way the teacher applies the learning model will have a major influence on the learning outcomes achieved by students. Successful teachers not only present material in a charismatic and persuasive manner but are able to actively involve students in the learning process.

Sates that the success of students in achieving learning outcomes is very dependent on the skills of teachers in applying learning models so that teachers should be able to play, understand, and design learning models that are applied in every lesson perfectly. [1]

Teachers should not only explore the content of the material but also should be able to play an interesting learning model that can involve students in learning activities and improve learning outcomes and the learning activities developed are collaborative and cooperative. The pillars of $21 \mathrm{st}$ century skills that include the $4 \mathrm{Cs}$ are communication (communication skills), creativity and innovation (creativity \& innovation), collaboration (collaboration) critical thinking skills (critical thinking and problem solving). [2]

In essence, learning is a process of behavior change that leads to changes in humans which are shown in attitudes, interests, or abilities in proficiency in a performance. Through learning activities will make a person change his behavior in aspects of knowledge, attitudes, and skills . [3]

Based on the results of observations looking at PPKn learning at MTS Yapiq, it was found that teachers were less varied in using learning models and tended to use lecture learning models, teachers presented material and students listened so that students did not participate in learning and communication was only one way, learning activities tended to be teacher center

The choice of learning model by educators is very important because through the learning model it can be 
a reference in preparing tools, learning media and knowing the steps in learning so as to determine the teacher's teaching design by being a facilitator to students in order to achieve learning objectives. That in implementing learning strategies the teacher is based on an approach that will be used and when implementing learning strategies various kinds of learning methods are also determined. [4 ]

An alternative solution in overcoming problems at MTS Yapiq is to apply a MURDER type cooperative model with the help of interactive quiz media for the development of learning input, process, and output. MURDER is a learning model adapted from Hayes' book which was adapted from Bob Nelson's book "The Complete Problem Solver." MURDER is structured according to the stages of learning, namely Mood, Understand, Recall, Digest, Expand, Review [5]

The first MURDER type of cooperative learning model was introduced by Hythecker, Dansereu, \& Rocklin which can also be called the Cooperative Script with its development model in the form of the MURDER cooperative learning model. In his research, this model of cooperative learning is recognized to improve learning outcomes [6]

The problems in pene Litian are b How can an experimental class students' responses to the application of media-assisted learning model MURDER interactive quiz in learning PPKn Meanwhile, the purpose of this research was to find out the response of experimental class students to the application of the MURDER learning model assisted by interactive quiz media in PPKn learning.

\section{THEORETICAL REVIEW}

\subsection{Citizenship Education}

Civic education is an interdisciplinary education. As described education merup a right of a political democracy based education programs are reinforced by other science, education in schools and communities. It was all processed with the aim to train students dal a $\mathrm{m}$ thinking critically, and behave and act in order to prepare for democratic citizens in accordance with the 1945 Constitution and Pancasila. [7]

That in the new paradigm, civic education is one of the fields of study that carries out the national mission to educate the life of the Indonesian people through the corridor of "value based education". [8]

\subsection{Learning Model}

Learning models are generally designed based on principles and theories of knowledge. The learning model developed by experts is based on the principles of learning, psychological, sociological, and other appropriate theories. The learning model studied based on learning theory can be classified into four models. The model that describes the general pattern or learning behavior in order to achieve the intended learning objectives and the learning model is a procedure that can be useful in curriculum formation in planning, designing teaching materials, guiding learning. The learning model can be a pattern that can be chosen by the teacher which must be in accordance with the learning objectives to be achieved [9]

\subsection{MURDER Type Cooperative Model}

The MURDER type of cooperative learning model was first introduced by Hythecker, Dansereu, \& Rocklin. MURDER is a learning model adapted from Hayes' book which contains about the stages in teaching and learning activities.

The MURDER acronym in danserau consists of Mood, Understand, Recall, Digest, Expand, Review. [10]. Meanwhile, Jacob MURDER's opinion is that a learning model comes from cognitive psychological thinking which is arranged according to the stages of learning, namely Mood, Understand, Recall, Digest, Expand, Review.

\subsection{Learning Outcomes}

Learning outcomes are a result obtained through the act of learning and teaching, $\mathrm{d} i$ where the results will be a good learning fun effects, and has a good influence on the business yan rest of the future, while students who had studied hard will get optimal results. Learning outcomes are a realization of potential as well as a person's capacity to progress [11].

\subsection{Interactive Quiz Media}

Media learning is a useful tool as a medium to convey a message in the learning activities that can stimulate the mind, feelings, concerns, interests of students in order to achieve a goal. [12 ].

Learning media that can be implemented are interactive quizzes. Examples of useful learning media that can be applied in the classroom are those used by students and teachers using interactive quizzes with the help of the Quizizz application. Quizizz is a learning application that is useful for Civic Education learning activities in the classroom. Quizizz is a web-based learning media that contains questions that have been made by the teacher that students can do as well as online quizzes. [13 ]

\section{METHOD}

In this research, the form of design used is Nonequivalent ( Pretest and Posttest) Control Group Design in quasi-experimental approaches is the most frequently used in research. [14 ]

The experimental class or the control class were selected in a non-random way. The pretest and posttest were carried out by the experimental class and the control class. But the treatment was given only to the 
experimental class using the MURDERS learning model with interactive quiz media and the control class did not get any treatment.

The location in the study was carried out at MTS Yapiq, Bandung Regency and researchers took samples, namely class VIII D which became the experimental class and class VIII $\mathrm{C}$ which became the control class while the number of students in the experimental class and control class were 30 students.

The procedure in this research is pre research which consists of pre research, research planning and research implementation. In the pre-research, the first thing to do is submit a research proposal which contains the formulation of the problem, the study of research theory and methodology and an overview of the research to be carried out. Then in the research planning, the researcher designs and makes instruments and makes research tools that contain questions that will be used in the implementation of the pretest and posttest. At the implementation stage of the research is the step of collecting data. The research was carried out in class VIII D as the experimental group and class VIII C as the control group. The purpose of this study was to determine the effect of applying the MURDER model through Quizizz on student learning outcomes in Civics learning.

The instruments in this study consisted of tests, attitude scales, and questionnaires. The test is used to determine the students' ability in mastering the material. Researchers provide tests that are presented in the form of questions that can be used to find out the results of Civic Education learning before the implementation of the MURDER model and after the implementation of the model in learning. Then the attitude scale in this study uses an attitude scale that uses a linkert scale approach which includes 5 scales. The scale is used to measure the development of student attitudes regarding the effectiveness of the Quizizzassisted MURDER cooperative model on student learning outcomes. Furthermore, a questionnaire was given to the VIII students of SMP Yapiq by the researcher, which is an experimental class aimed at knowing student responses in the application of the MURDER learning model in PPKn learning.

The data analysis technique in this study was the data obtained in the study and then analyzed to test the hypothesis. However, before testing the hypothesis, it was mandatory to test the analytical prerequisites which included testing for normality and homogeneity. Based on the results of data collection that has been collected then the data is analyzed and the data is processed, when analyzing the data the researcher uses statistical data analysis based on quantitative data, namely data shown by numbers. Analyzing data is grouping data based on variables and types of respondents, stabilizing data based on all respondent variables, presenting data based on each variable studied.

\section{RESULT AND DISCUSSION}

Result

In this study, to determine student responses by implementing the Cooperative Learning model type MURDER assisted by interactive quizzes, data calculations were carried out by distributing closed questionnaires so that students only gave limited answers from the choices given to students. The MURDER type of cooperative learning model assisted with interactive quizzes is applied in PPKn learning which includes several activities, namely introduction, core and closing. So that the data processing is done by calculating the average of each aspect of these activities.

In order to get clearer information related to student responses in the implementation of Civics learning activities through the use of the MURDER type cooperative model assisted by interactive quiz media, namely preliminary activities,core activities an dclosing activities. Preliminary activities: it consists of opening activities, apperception, conveying KI, KD and learning objectives. In the opening activity, it was 4.59 , but to convey apperception, $\mathrm{KI}$ and $\mathrm{KD}$ or learning objectives the average score obtained was 4.29

Core activities: consisting of student-centered learning, interactive learning, curriculum-based learning and the application of the MURDER type cooperative model assisted by interactive quiz media. In student-centered activities the average score obtained is 4.14 , then in interactive activities the average score obtained is 4.12 and for curriculumbased learning activities, an average score of 3.75 is obtained as well as in the application of the model. MURDER cooperative type assisted by interactive quiz media in learning the average score obtainedis 4.06 .

Closing activities: consisting of conclusions, reflections and evaluations. In the conclusion of the of the learning activity, an average score of 4.40 was obtained, then the reflection activity obtained an average of 4.12 .

Student responses to the application of the MURDER Assisted by interactive quiz media on the activities of the introduction, the core and the cover obtained results which showed that the indicators of activity of learning has value rat a average of $>3$, which shows that the indicators of these activities have a very good response in Civic education learning, from the introductory, core and closing activities, very good results were obtained and the students indicated that they strongly agreed about the implementation of the MURDER type cooperative model assisted by interactive quiz media in civic education learning. 


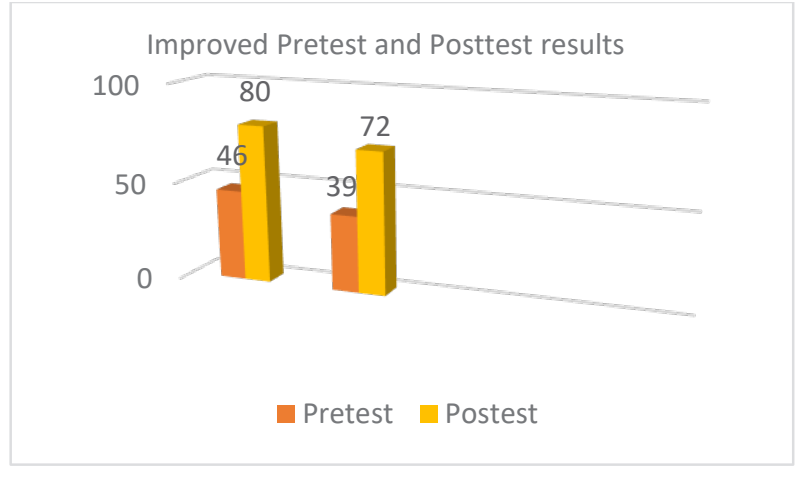

Picture 1 Improved Pretest and Postest Result

The picture above shows that for the experimental class the average score for the pretest is 46 and after receiving treatment through the application of the MURDER type cooperative model assisted by Quizizz, student learning outcomes based on the posttest increased by 80 in the experimental class, improving cognitive aspects was 34 points.

Then in the control class the learning outcomes obtained before using the STAD Student Teams Achievement Divisions learning model on the cognitive aspects of the pretest results were 39 and after applying the STAD Student Teams Achievement Divisions learning model the score became 72 in the posttest. So that in this study the highest learning outcomes showed an increase in the cognitive aspect.

\section{Discussion}

The cognitive aspect is the most visible aspect of the significant improvement. The increase in the average value is obtained when students in the learning process students understand themselves and then explain back to their friends, then knowledge construction occurs in students, namely by finding and changing the information found so that a thorough understanding or interpretation of the knowledge material is learned and through self-understanding with In their own language, students and students will find it easier to remember the material they are learning.

\section{CONCLUSION}

The application of the MURDER type of cooperative learning model (Mood, Understand, Recall, Detect, Elaborate, Review) is a type of cooperative learning that can create a student-centered and interactive learning. Based on the results of the students' responses in the experimental class by giving the application of the MURDER model treatment, getting a positive response from all accumulated learning activities both in preliminary activities, core activities, and closing activities, thus students have quite high interest and enthusiasm in participating in the learning process. using the MURDER model (Mood, Understand, Recall, Detect, Elaborate, Review)

\section{REFERENCES}

[1] Joyce, Bruce, Marsha Weil \& Emily Calhoun. (2009). Model of Teaching Model-Model Pengajaran. Yogyakarta: Pustaka Belajar.

[2] Junaedi, Beni, et al. (2020). Optimalisasi Keterampilan Pembelajaran Abad 21 Dalam Proses Pembelajaran Pada Guru Mts Massaratul Mut'allimin. : Jurnal Pengabdian Masyarakat, 16 (1), 2020: 63-72.

[3] Komalasari, Kokom. (2013). Pembelajaran Konstekstual Konsep dan Aplikasi. Bandung: Refika Aditama.

[4] Trianto. (2007). Model-model Pembelajaran Inovatif berorientasi Konstrutivistik. Surabaya : Prestasi Pusaka.

[5] Hayes, John R. (1989) The Complete Problem Solver. Published by the Franklin Institute Press Philadelphia, Pennsylvania.

[6] Cutis, J.B and Jill, S.G. (1991).Three Decades Of Cooperative Reading From Theori To Practice: Implication For The 21 st Century. A version of this paper was presented at the annual meeting of the American Educational Research Associaion, Chicago, IL. [Online]. Tersedia: https:/www.scribd.com/document/2879007/Coop erative- Reading-review-Bonk-and-SalisburyGlennon [10-02-2021]

[7] Somantri, Numan. (2001). Menggagas Pembaharuan Pendidikan IPS. Bandung: Rosdakarya.

[8] Komalasari, Kokom. (2013) Pembelajaran Konstekstual Konsep dan Aplikasi. Bandung: Refika Aditama.

[9] Joyce, Bruce, Marsha Weil \& Emily Calhoun. (2009). Model of Teaching Model-Model Pengajaran. Yogyakarta: Pustaka Belajar.

[10] Hayes, John R. (1989) The Complete Problem Solver. Published by the Franklin Institute Press Philadelphia, Pennsylvania.

[11] Sudjana, Nana. (2004). Dasar-dasar Proses Belajar Mengajar. Bandung: Sinar Baru Algensindo.

[12] Arsyad, A. (2014) Media Pembelajaran. Jakarta: PT. RayaGrafindo Persada.

[13] Citra, Cahyani Amildah \& Brillian Rosy. (2020). Keefektifan Penggunaan Media Pembelajaran Berbasis Game Edukasi Quizizz Terhadap Hasil Belajar Teknologi Perkantoran Siswa Kelas. Jurnal Pendidikan Administrasi Perkantoran (JPAP) Vol.8 No. 2.

[14] Creswell, Jhon. (2015).Riset Pendidikan: Perencanaan, Pelaksanaan, dan Evaluasi Riset Kualitatif \& Kuantitatif. Yogyakarta : Pustaka Pelajar. 